\title{
Determinants of Domestic Savings Mobilization Among the Rural Poor, The Contribution of Table Banking in Kenya
}

\author{
Joyce Kimosop ${ }^{1} \quad$ Josephat Cheboi Yegon ${ }^{2 *}$ \\ 1.Department of Management Science, School of Business and Economics, Moi University \\ 2.Department of Accounting \& Finance, School of Business and Economics, Moi University
}

\begin{abstract}
This study examined the determinants of domestic savings mobilization among the rural poor in Uasin-Gishu county, Kenya. The general notion is that the subsistence farmers are too poor to save. This seems to be unfounded given the fact that they are general excluded from formal financial services and studies on poverty in the country show that the average propensity of the rural households to save is higher than the national average. What are the factors which motivate small scale farmers to save? The study was conducted on 446 table banking groups under the aegis of JOYWO, a table banking grouping in Kenya. Data was collected using structured questionnaires from members of groups under the umbrella of JOYWO. The findings of the study indicates that household income had a positive and significant effect on savings mobilization while dependency ratio had a negative and significant effect on savings mobilization. Household size was not significant. The results point to the need to expose the rural poor to informal savings and financing models expected to enhance income generating capabilities of the rural poor and lower the level dependency through government welfare funding for senior citizens and essential services for the young
\end{abstract}

Keywords: Savings mobilization, Table banking, Rural Poor, Joyful Women Group.

DOI: $10.7176 /$ RJFA/10-6-02

Publication date:March $31^{\text {st }} 2019$

\section{Introduction}

There has been a sustained interest by economists, international organizations and governments in developing countries on the mobilization of deposits, not only to increase domestic savings and also to achieve sustained economic growth and development in order to strengthen domestic financial intermediaries (Vogel et al. 1984, Gonzalez-Vega \& Poyo 1986, Robinson 1994). Adriana de la Huerta (2010) found that household savings has positive effects on economic growth and poverty alleviation. Absence of savings deprives households of the mechanism to deal with unexpected variations in their income implying that any shocks could create some problems of human capital accumulation at early ages.

Studies on poverty in the country show that the incidence and the intensity of poverty in the villages is much higher than in the towns. Yet the available data about rural incomes and family budgets show that the average propensity of the rural households to save is higher than the national average. Economic theory indicates that savings represents the difference between income and consumption where income includes earnings from all sources during a year and is net of costs incurred in producing that income. Consumption on the other hand is the total amount of goods and services expended by the rural household during a year. Rural households manage to save in two ways: first, they increase their meagre incomes by 25 to 30 percent by non-farm incomes which come from off-farm work, business, and service; second, they squeeze their consumption expenditure on items which are not essential for survival. Household expenditure is broadly classified as (a) food expenditure and (b) non-food expenditure. Food expenditure can be further divided into (i) cereals and (ii) non-cereals. The general notion is that the subsistence farmers are too poor to save seems to be unfounded. What are the factors which motivate small farmers to save? What then is the rationale for this savings behaviour? This is an area in which not much work seems to have been done.

In Kenya, financial services are provided by a variety of intermediaries that are part of the country's financial system. There are three types of financial service providers being - informal, quasi-formal and formal. The distinction is primarily based on whether there is a legal framework that provides remedy to lenders and protection to depositors. Although the formal financial services are provided by financial institutions licensed by the central bank of Kenya and subject to banking regulations and supervision, quasi-formal financial services are not regulated by the central bank. These institutions are usually licensed and supervised by other government agencies. On the other hand, informal financial services are provided by individuals and institutions outside the structure of government regulation and supervision. Poor people face partial or full exclusion from the financial sector and cannot take advantage of the opportunities associated with access to financial services. Access to financial services implies the absence of any hurdles (both price and non-price barriers) to the use of needed financial services. Exclusion can be voluntary or involuntary, where voluntary exclusion occurs in a case where an individual has access to financial services but is not in need of while involuntary exclusion arises where price and/or non-price barriers prevent the access to these services. 
Following liberalization of the economy in Kenya in 1992 and the growing influence of the cash economy in rural areas, associations like merry go rounds, village savings and loans (VS\&L) and rural savings and credit cooperatives (RUSACCOs) and table banking have become very instrumental in savings mobilizations and provision of micro loans to members in rural areas of the country. These models are preferred by rural household due to easy accessibility of the services, relatively low interest rates, customer care, minimum deposit requirement, ease of access for savings, and informal nature of transactions (Adeyemo 1982, Onyenwaku and Ozoh 1992).

\subsection{Evolution of Table Banking}

The provision of financial services to the rural poor has undoubtedly taken a long and mutating journey to date. Care International, a Non-Governmental Organization, developed 'Village Savings and Loan' (VS\&L) model initially piloted at Matu Masa Dubara (MMD) in Niger and currently replicated in over 21 countries worldwide, 17 of them in Africa. The strength of this model is attributed to costs per client. A fully financially stable MFI costs between \$200-300 per client whereas VS\&L costs between \$25-40 per client (Allen, et al., 2004).

The VS\&L model in Niger was further improved in other countries over time, notably Jozani Savings and Credit Associations (JOSACA) in Zanzibar. This model became open to both genders and the economic capability of each individual member was considered. It also changed the payout mechanism which formerly distributed all savings and dividends. Additionally, source of funding was stretched to accommodate external financing (Allen, et al., 2004). (see table 1)

The JOSACA model further mutated into a new model called 'table banking'. Table banking is a group based funding strategy in which members save and borrow immediately from the same savings. The size of loans depends on the amount of money on the table saved at one point. Members borrow money in form of either short term or long term loans. The interest is retained by the group as profit for the group. A member is given the loan according to the amount of her shares or savings in the table. This encouraged members to save more in order to increase their borrowing capacity.

Joyful Women Organization in Uasin Gishu County has adopted this model where for short term loans, members are granted twice the amount of shares accumulated and are supposed to repay it after a period of one month. Long term loans are granted thrice the accumulated shares and are repaid in 12 or 24 monthly installments, with an interest of $10 \%$ on reducing balance model. Out of the $10 \%$ interest, $2 \%$ is credited to members' savings pro rata to savings as a bonus. Another $7 \%$ is paid out as dividends at the end of the financial year. The remaining $1 \%$ is taken by Joyful Women Organization for administrative purposes.

Joyful Women Organization is currently running a one year capacity building program that trains its members on Group dynamics, Leadership, Entrepreneurship, Book keeping \& Banking, Loans and grants among others. This training provided them with the basic skills to mobilize their savings and manage their own resources and affairs as they moved toward establishing a permanent system of savings and credit.

The program is governed by a board of directors appointed by the group members who are the shareholders of the program. The board is charged with the responsibility of giving policy direction, appointment of program manager, approval of credit policies, fund raising among others.

The table below captures the transition on rural savings mobilization and credit access from VS \&L to the new concept of table banking based on specific characteristics.

Table 1: Transition of VS\&L to Table Banking

\begin{tabular}{|c|c|c|c|}
\hline & \multicolumn{3}{|c|}{ RURAL FINANCE MODEL } \\
\hline Characteristic & $\begin{array}{ll}\text { MMD } & \text { NIGER } \\
\text { (VS\&L) } & \end{array}$ & $\begin{array}{l}\text { JOSACA } \\
\text { (VS\&L) }\end{array}$ & $\begin{array}{l}\text { JOYFUL KENYA } \\
\text { Banking) }\end{array}$ \\
\hline Gender & Female & Mixed & Mixed \\
\hline Normal meeting frequency & Weekly & Weekly & Monthly \\
\hline Contribution type & Equal & Variable shareholding & Variable shareholding \\
\hline Payout mechanism & End of cycle: all & End of cycle: partial & Dividend + bonus \\
\hline Loan terms & $\begin{array}{l}\text { Short term } \quad(1 \\
\text { month })\end{array}$ & Short term (1-3 months) & Short \& Long term \\
\hline Loan limits & None. Agreed & 3 times shareholding & $\begin{array}{l}\text { ST }-2 \text { times; LT }-3 \text { times } \\
\text { shareholding }\end{array}$ \\
\hline $\begin{array}{l}\text { Principal means of record } \\
\text { keeping }\end{array}$ & Recall & Written & Written \\
\hline Strong box & Yes & Yes & No \\
\hline Source of finance & Self & Self \& external & Self \& external \\
\hline
\end{tabular}

Joyful Women Organization through 'table banking' model has unveiled a vehicle aimed at fulfilling the MDG goals and Economic Recovery Strategy for Wealth and Employment Creation agendum on poverty alleviation among the citizenry (GoK, 2005). 
Given that, it is still not clear what factor determines household savings mobilization in the rural setting. Hence, the purpose of this paper is to identify and examine the determinants savings of rural household table bankers as well as ascertaining which of these factors significantly determines household savings mobilization in Uasin Gishu County, Kenya.

\section{Determinants of Savings mobilization}

Keynesian Economists have presented a notion of a single variable determining savings in the literatures. This stance has been criticized by finance studies because a single variable or factor cannot unilaterally determine the saving pattern of several households in the world at large (Yusuf and Peters, 1984). Household Income The level of income as a determinant of savings was the major idea of the Keynes. His submission indicates that savings has a positive effect towards income, meaning that an increase in income results in an increase in savings ceteris paribus (Dasgupta, 1974). Nwakeze (2000) pointed out that households try to balance their accounts by spending according to their income that is households' consumption is a function of their income. There are contrasting approaches to the estimation of household income and the distinction between gross income, net income and disposable income. Kahlon et al (1972) obtained farm family income by adding all the incomes from farm, non-farm activities and borrowings from institutional and non-institutional sources. Disposable income was compiled by deducting production expenditure from farm family gross income. Chauhan et al (1972) defined farm business income as gross farm income less farm business operating charges. Household size is an important factor that determines household income, expenditure and consequently savings. A typical household size, according to Atala (1984) is constituted by the summation of the number of wives, children, relatives and dependents living in the household at the time of any investigation. Olukosi and Ogungbile (1991) reported that the average family size in Nigeria is about six to seven persons per family which is agreeable to the Kenyan context. Yinusa (1991) found an inverse relationship between savings and household size. Nganga (1992) and Okanigbe (1987) reported similar results. Synder (1971) showed that the probability for positive savings for a sample of Sierra-Leone households was unaffected by family size. Durojaiye (1991) reported similar findings under implausible assumptions, the impact of increased household size on savings rate is ambiguous; savings may increase, decrease or remain unchanged (Kelly, 1976). Dependency Ratio is the proportion of the nonworking population in the young age bracket which is between the age of 0-16 and in the older age group of 65 and above to the total population. Higher dependency ratio has a negative effect on savings due to higher consumption. It was observed that with high consumption, resulting from large number of dependents have an adverse effect on income reducing savings.

\subsection{Methodology}

This study was conducted in Uasin Gishu County in Rift Valley province in Kenya. Survey research design was used in this study given that it is a common strategy in business and management research. The respondents were the members of the 446 table banking groups under the aegis of JOYWO. A Survey strategy was used in this study because it is perceived to be authoritative by people in general and it is easily understood, and can therefore result in valuable findings if correct procedures are followed (Saunders et al., 2003; Clover et al., 1979; Nassiuma, 2000, 2004; Peil, 1995).

The target population for this study was 11800 members drawn from 446 groups. The sample size was 120 drawn from randomly selected groups in rural Uasin Gishu. The individual elements for this study were selected from the sampling frames using probability sampling techniques because representative samples could help in achieving the goals of this study. The specific sampling methods used in this study were stratified and random sampling. The sample was achieved by stratifying the population into rural and urban groups, random was used to select the groups as well as respondents from the selected groups.

\subsection{Model Specification}

Descriptive statistics, including frequency distribution and percentages were used to analyze the socio-economic characteristics of the sampled farmers. OLS regression was used to quantitatively determine the factors that influence savings mobilization among the respondents in the study area.

The function postulated is implicitly presented by the following:

The relationship was as follows;

$\mathrm{Y}=\beta 0+\beta 1 \mathrm{X} 1+\beta 2 \mathrm{X} 2+\beta 3 \mathrm{X} 3+\varepsilon$

Where:

$\beta 0, \beta 1, \beta 2, \beta 3, \beta 4)$ are coefficients.

$\mathrm{Y}=$ Savings mobilization

$\mathrm{X} 1=$ Household income

$\mathrm{X} 2=$ Household size

$\mathrm{X} 3=$ Dependency ratio 
$\varepsilon=$ error term.

The regression coefficient ' $\beta 0$ ' is the $\mathrm{Y}$ intercept; while $\beta 1, \beta 2, \beta 3$, are the net change in $\mathrm{Y}$ for each change of $\mathrm{X} 1, \mathrm{X} 2$, and $\mathrm{X} 3$.

The error term $(\varepsilon)$ is a random variable with a mean of zero, which captures those variables that cannot be quantified.

\subsection{Findings}

\section{Socio-economic characteristics of the respondents:}

Table 2 revealed that the majority of the respondents were aged between $36-45$ years $(30.8 \%)$ and $26-35$ years (29.8\%). About $21.2 \%$ fell between $46-55$ years, $12.5 \%$ above 65 years and $5.8 \%$ were aged below 25 years. This implies that they are within the active working years to be productive enough to mobilize some savings and also be in need of credit for meeting the needs of their dependents. This observation is shown by the household size being highest in the category of 4-6 dependents accounting for $45.2 \%$ of the respondents. Analysis revealed that $63.5 \%$ of the respondents were married while $11.5 \%, 20.2 \%$ and $4.8 \%$ were single, widowed and divorced respectively. This may have a positive effect on participation in table banking due to the need to raise finance for family improvement in addition to knowing that a back up exists in case the spouse cannot repay the extended loan. The table showed that $51 \%$ of the respondents' highest level of education was primary school while $33.7 \%$, $13.5 \%$ and $1.9 \%$ were for secondary, college and university respectively. This trend explains the inability of the respondents to access banking facilities which persuades them to join table banking for mobilizing savings and access to credit.

Table 2: Socio-economic Characteristics of Respondents

Variables $\quad$ Frequency $\mathbf{N}=\mathbf{1 0 4}$

\section{Percentage}

Age (Years)

$<25$
$26-35$
$36-45$
$46-55$

$6-5.8$

$\begin{array}{lr}6 & 29.8\end{array}$

$32-30.8$

$22-21.2$

Marital Status

$\begin{array}{lrr}\text { Single } & 12 & 11.5 \\ \text { Married } & 66 & 63.5 \\ \text { Divorced } & 5 & 4.8 \\ \text { Widowed } & 21 & 20.2\end{array}$

Number of Dependents

$\begin{array}{lll}<3 & 22 & 21.2 \\ 4-6 & 47 & 45.2 \\ 7-9 & 20 & 19.2 \\ >10 & 15 & 14.4\end{array}$

Level of Education

\begin{tabular}{lrr} 
Primary & 53 & 51 \\
Secondary & 35 & 33.7 \\
College & 14 & 13.5 \\
University & 2 & 1.9 \\
\hline
\end{tabular}

\subsection{Regression Analysis}

Multiple regression analysis done as shown in Table 3 determined the relationship between saving mobilization of table bankers and the three variables investigated in this study.

Table 3: Regression results

\begin{tabular}{|ll|l|l|l|l|l|}
\hline \multicolumn{2}{|l|}{ Model } & \multicolumn{2}{|l|}{ Unstandardized Coefficients } & Standardized Coefficients & t & Sig. \\
\cline { 1 - 5 } & & $\mathrm{B}$ & Std. Error & Beta & Zero-order & Partial \\
\hline 1 & (Constant) & 12.262 & 2.552 & & 4.804 & .000 \\
& Household Income & .285 & .066 & .483 & 4.340 & .000 \\
& Household Size & -.101 & .127 & -.093 & .971 & .054 \\
& Dependency ratio & -.096 & .044 & -.300 & 2.179 & .003 \\
\hline
\end{tabular}

a. Dependent Variable: Measurement of Savings Mobilization

The regression equation was:

$\mathrm{Y}=12.262+0.285 \mathrm{X} 1-0.101 \mathrm{X} 2-0.096 \mathrm{X} 3$ 
Where;

$\mathrm{Y}=$ the dependent variable (Savings Mobilization)

$\mathrm{X} 1=$ Household income

$\mathrm{X} 2=$ Household size

$\mathrm{X} 3=$ Dependency ratio

The regression equation above has established that taking all factors into account (Savings mobilization as a result of household income, household size and dependency ratio)

The findings presented also shows that taking all other independent variables at zero, a unit increase in household income will lead to a 0.285 increase in the scores of savings mobilization; a unit increase in household size will lead to a 0.101 decrease in saving mobilization and a unit increase in dependency ratio will lead to a 0.096 decrease in savings mobilization.

\subsection{Summary of the Findings}

The objective of this study was to examine the determinants of domestic savings mobilization among the rural poor, the contribution of table banking in Uasin Gishu County. The study was conducted on 446 table banking groups under the aegis of JOYWO that constituted the sample size. To collect data, the researcher used a structured questionnaire that was administered to the respondents.

The respondents were the members of groups under the umbrella of JOYWO.

From the findings, majority of the respondents were between $26-45$ years old. On education level majority of respondent had secondary education. On the number of dependents, majority had 4-6 dependents and were married.

Household Income: The survey revealed that household income had a positive and significant effect on savings mobilization which implied that and increase in income will result in an increase in savings of the rural poor. This is important to note given the modalities of increasing income varying from household to household. These results were consistent with the postulations of Keynnesian Economists among many other studies like (Dasgupta, 1974 and Nwakeze 2000). Household size was found to be negative and significant, meaning that as family sizes increased savings reduced. These results were not significant meaning that no reasonable conclusion can be made given unexplained varying results in different sections of the sample collected. Dependency ratio was found to negative and significant meaning consistent with the findings of Jappelli and Modigliani (1998) that a higher number of dependents from the very young to the older citizens drain the family coffers hence no savings.

\subsection{Recommendation}

The success of the Table Banking is directly attributable to the responsiveness of the product to the members' needs. It provides them with desired savings and credit services, while not costing them anything to access those services, other than patience and some of their own time. Because there is no leakage of funds outside of the group, all of the benefits accrue to the group, enhancing the interest in the members to respect the rules. Since they are borrowing their own money, moral hazard is drastically reduced to the point that there is virtually 100 percent repayment among the Table Banking groups. The study recommends that given the importance of income of the household to savings mobilization, greater attention should be given on how to increase income of a rural household. A further interrogation of household size should be done to determine the composition of the household and its specific contribution to savings mobilization. Government should institute measures to reduce dependency in order to free more of the income generated for savings. This can be done through welfare schemes for the old and the government funding basic services to young.

\section{References}

Allen, Hugh and Pauline Hobane (2004): 'Impact Evaluation of Village Savings and Loan in

Kupfuma Ishungu, February 2004. CARE Harare and Arusha.

Atieno. R (2001) Formal and informal institutions' lending policies and access to credit by small-scale enterprises in Kenya: An empirical assessment. Nairobi: University of Nairobi AERC Research Paper 111 African Economic Research Consortiums, November 2001.

Bell, J. (1999). Doing your research project ( $3^{\text {rd }}$ ed.). Buckingham: Open University Press.

Brannen, C. (2010). An Impact Study of the Village Savings and Loan Association (VSLA) Program in Zanzibar, Tanzania. Masters Thesis, Wesleyan University.

Dagnelie, O., \& LeMay-Boucher, P. (2008). ROSCA Participation in Benin: A Commitment Issue. UFAE and IAE Working Paper

De Mel, S., McKenzie, D., \& Woodruff, C. (2009). Are women more credit constrained? Experimental evidence on gender and microenterprise returns. American Economic Journal: Applied Economics, 1-32.

Esson, R. (2003). Savings \& Savers: An Analysis of Saving Behavior among Cape Town's Poor. Centre for 
Social Science Research (CSSR) Working Paper No. 59, p1 - 45

Joseph, K. (2013). Financing Small and Micro Enterprises in Ghana. Challenges and determinant in accessing bank credit. International journal of research in social sciences Ghana.

Kothari, C.R. (2003). Research methodology: Methods and techniques. (2 $2^{\text {nd }}$ ed.). New Age International (P) Ltd

Matin, Imran. 2002. New Thinking and new Forms of Micro-financial Service Provision in Bangladesh: a Comparative Study of ASA, Safesave and Gono Bima. University of Manchester, Institute for Development Policy and Management. Manchester, UK.

Available at: http://idpm.man.ac.uk/wp/fd/fdwp37abs.htm

Mohini, M., (2007). Expanding Access to Finance: Good Practices and Polices for Micro, Small and Medium Enterprises. Washington: The World Bank.

Mugenda, M.O. \&Mugenda, A.G. (1999). Research Methods: Quantitative and Qualitative Approaches. Nairobi: ACTS Press.

Navajas, Sergio and Claudio Gonzalez-Vega. June 2000. Innovative Approaches to Rural Lending: Financiera Calpia in El Salvador. Ohio State University. Columbus, Ohio.

http://aede.osu.edu/programs/RuralFinance/pdf

Rahman A, (1999). Women and microcredit in rural Bangladesh: anthropological study of the rhetoric and realities of Grameen Bank lending.

Retrieved from http://www.cabdirect.org/search.html.

Saunders, M., Lewis P. and Thornhill A. (2003). Research methods for business Students. (3rd ed.) England: Prentice Hall.

Skees, Jerry. (2003). Challenges in Risk Management in Rural Financial Markets: Blending Risk Management Innovations with Rural Finance. Document presented at the Conference "Paving the Way Forward: An International Conference on Best Practices in Rural Finance"

Verhoef, G. (July, 2002). Money, credit and trust: Voluntary savings organizations in South Africa in historical perspective. Paper presented to the International Economic History Association

Congress, Buenos Aires, Argentina. 